\title{
El impulso constructivo de la catedral de Oviedo durante el reinado de Isabel la Católica: el pórtico y obras contemporáneas ${ }^{1}$
}

\author{
Carmen $M^{a}$ Labra González \\ Universidad de Oviedo
}

\begin{abstract}
RESUMEN. A principios del siglo XVI se inician en la catedral de Oviedo las obras de la fachada. El pórtico y la torre única se erigen como dos elementos significativos que, tal y como se indica en este trabajo, forman parte de una serie rastreable en todo el norte de Europa. El pórtico constituye un ejemplo aislado dentro del panorama castellano, mientras que la torre, a pesar de ser comparada con las de Burgos y León, se singulariza por su unicidad y traza.

Palabras clave: Arquitectura tardogótica, catedral de Oviedo, catedral de León, Juan de Badajoz el Viejo, Pedro de Bueras, pórtico, torre, influencia extranjera.

RÉSUMÉ. Au début du XVIe. siècle s'initien dans la cathédrale d'Oviedo les œuvres de la façade. Le porche et la tour unique sont érigés comme deux éléments significatifs, qui comme il est indiqué dans ce travail, ils font partie d'une série connue au nord de 1'Europe. Le porche constitue un exemple isolé à Castille, tandis que la tour, bien qu'elle soit comparé avec celles de Burgos et León, est distinguée par son unicité et trace

Mots-Clés: architecture gothique tardive, cathédrale d'Oviedo, cathédrale de León, Juan de Badajoz "El Viejo", Pedro de Bueras, porche, tour, influence étrangére
\end{abstract}

Durante el reinado de Isabel la Católica tuvo lugar en la catedral de Oviedo una de las etapas constructivas más importantes e innovadoras. Frente al escaso protagonismo que la diócesis asturiana podía tener con respecto a otras como León, Burgos o Toledo y a pesar de las dificultades económicas que siempre marcaron el ritmo de las obras, en ese momento las prelaturas de varios obispos vinculados a la Corona dieron a la fábrica el impulso definitivo y el resultado final pudo ser más innovador de lo que hasta ahora se pensaba.

Resulta fundamental, a la hora de abordar el estudio de la diócesis ovetense, el trabajo de Francisco de Caso Fernández La Construcción de la Catedral de Oviedo (1293 - 1587), en

\footnotetext{
${ }^{1}$ Este trabajo se ha realizado dentro de Programa de Becas Predoctorales para la formación en Investigación y Docencia del Gobierno del Principado de Asturias con cargo a fondos provenientes del Plan Investigación, Desarrollo Tecnológico e Innovación de Asturias (FICYT).
}

el que muy acertadamente se han analizado los diferentes momentos constructivos vinculándolos a obispos emprendedores. Para el periodo que nos ocupa son fundamentales las prelaturas de Alonso de Palenzuela (1469 - 1485); Juan Arias del Villar (1487 - 1498); Juan Daza (1498 - 1502) y Valeriano Ordóñez de Villaquirán $(1508-1512)^{2}$, sobre todo la del segundo de ellos, sin olvidar las de Gonzalo de Villadiego (1485 - 1487) y García Ramírez de Villaescusa (1502 - 1508) que continuaron en la línea de sus respectivos antecesores ${ }^{3}$.

Recientemente están siendo de gran interés los estudios sobre la fachada catedralicia y el

\footnotetext{
2 M. J. SANZ FuenTES, "Valeriano Ordóñez de Villaquirán, Abad de Alcalá la Real, Obispo de Oviedo (1508 1512). Documentos para la historia de su episcopado", II Jornadas de Historia en la Abadía de Alcalá la Real: homenaje a D. Antonio Linage Conde, Jaén, 1999, pp. 543-565.

${ }^{3}$ F. DE CASO FERNÁNDEZ, La construcción de la Catedral de Oviedo (1293 - 1587), Oviedo, 1981.
} 
entorno de la misma realizados por $\mathrm{M}^{\mathrm{a}}$ Pilar García Cuetos en los que se presenta al cierre de la catedral como un cuerpo innovador, funcional y culminador de las soluciones tardogóticas dentro del panorama arquitectónico castellano ${ }^{4}$.

En estos momentos interesa especialmente el episcopado de Juan Arias del Villar, (1487 - 1498), uno de los más fructíferos e importantes pues supuso el cierre del templo y la construcción de la sillería de coro. La vinculación a la Corona de este obispo viene dada por el cargo de Presidente de la Real Chancillería de Valladolid que ostentó desde el 2 de mayo de 1492 hasta el 28 de junio de 1501. Paralelamente a este cargo también formó parte del Consejo Real. $^{5}$

En este momento tuvo lugar la llegada a la catedral de Oviedo de dos maestros de primera fila dentro del panorama artístico castellano: por un lado Bartolomé de Solórzano como máximo responsable de las obras y por otro un taller escultórico vinculado a Alejo de Vahía.

Con respecto a Bartolomé de Solórzano es sabido que llegó a Oviedo procedente de Palencia, donde había trabajado en la catedral y en el convento de Santa Clara, encargado por Juan Arias del Villar. Más adelante, siendo Presidente de la Real Chancillería de Valladolid el obispo ovetense, intervino Solórzano en las obras del colegio de San Gregorio de esa ciudad y por encargo del mismo construyó el puente

\section{-}

${ }^{4}$ M. P. García Cuetos, "Culminación y transformación de la catedral de Oviedo", El libro de la Catedral de Oviedo. Escrito en la piedra, Oviedo, 1997; "Entre la civitas y la urbs. La inserción urbana de la catedral de Oviedo", E. CARRERO Y D. RICO (Eds.), Catedral y ciudad medieval en la Península Ibérica, Murcia, 2004, pp. 99-140; "Juan de Badajoz, el Viejo, entre Oviedo y León. Nuevas hipótesis sobre maestros y torres en el tardogótico hispano", Congreso Internacional "La Catedral de León en la Edad Media", León, 2004, pp. 565-574; "Los Pasos Perdidos. El trazado urbano de Oviedo bajo la Plaza de Alfonso II", Estudios en homenaje a Eloy Benito Ruano, Oviedo, 2004, pp. 763-796; "Turris Babylon. Asimilación y creación del lenguaje tardogótico en la torre de la catedral de Oviedo", Studium ovetense. Homenaje a Don Raúl Arias del Valle, (en prensa). Las últimas investigaciones sobre este tema fueron expuestas por García Cuetos en el Coloquio SIREM/AMERIBER, BORDEAUX III "Imágenes del poder. Poder de las imágenes en la España Medieval (siglos XI-XVI)" en la comunicación titulada "Las señoras del horizonte. Las flechas caladas como expresión del poder y la recreación hispana de un modelo europeo" que tuvo lugar en Burdeos en marzo de 2006.

${ }^{5}$ M. DE LA S. MARtín POSTIGO, Los presidentes de la Real Chancillería de Valladolid, Valladolid, 1982, p. 33. del Boecillo, pudiendo afirmarse, pues, que es Juan Arias del Villar quien favoreció la llegada a Oviedo del maestro transmerano. ${ }^{6}$ Se le documenta por primera vez en Oviedo en 1492 y hasta hace poco tiempo se pensaba que su vinculación a la diócesis ovetense terminaba en 1500, sin embargo $M^{\mathrm{a}}$ Pilar García Cuetos considera que su maestrazgo debió extenderse hasta 1502 , cuestión fundamental a la hora de abordar el estudio del pórtico como se verá más adelante $^{7}$.

La otra llegada a Oviedo de un taller destacado la constituye un grupo de tallistas vinculados a Alejo de Vahía encargados de realizar la sillería $\mathrm{coral}^{8}$. El principal debate que se cierne sobre esta obra es el de su autoría; parece claro que los artistas que trabajaron aquí habían pasado antes por la librería de la catedral de León, sin embargo mientras que C. J. Ara Gil y más tarde M. D. Teijeira, recogiendo la hipótesis de la primera, opinan que al frente del taller se encontraba Alejo de Vahía, Joaquín Yarza considera más acertado pensar en un seguidor del maestro alemán que en el propio maestro ${ }^{9}$.

La única matización al respecto que desde aquí podemos hacer es la sugerencia de un posible origen bávaro de Alejo de Vahía ${ }^{10}$. Ninguno de los autores anteriormente citados ha especulado acerca del origen del escultor más allá de lo que en su día publicó Ignace Vandevivere, el cual le suponía una formación de origen renana a juzgar por las similitudes entre su esti-

\section{-}

6 J. M. AzCÁRATE, "Bartolomé de Solórzano y el puente del Boecillo", Boletín de Valladolid, t. XXIV, 1958, pp. 177 - 180; F. DE CASO FERNÁNDEZ, op. cit., pp. 254 - 264.

${ }^{7}$ M. P. García Cuetos, "Juan de Badajoz, el Viejo, entre Oviedo y León...”, p. 568.

${ }^{8}$ El estudio más completo sobre la sillería coral ovetense es el realizado por M. D. TEIJEIRA PABLOS, La sillería de coro de la Catedral de Oviedo, Oviedo, 1998.

${ }^{9}$ C. J. ARA GIL, "La intervención del escultor Alejo de Vahía en la sillería de coro de la Catedral de Oviedo", Anales de Historia del Arte, 4, (1993-1994), Homenaje al profesor Dr. D. José María de Azcárate, pp. 341-352; M. D. TEIJEIRA PABlos, op. cit.; J. YARZA LUACES, Alejo de Vahía, mestre d'imatges, Barcelona, 2001, p. 106. Estas hipótesis las recogen E. CARRERO SANTAMARÍA, "Una alegoría y un sarcasmo en la librería de la catedral de León", Imágenes y promotores en el arte medieval. Miscelánea en homenaje a Joaquín Yarza, 2001, pp. 291, y M. P. GARCÍA Cuetos, op. cit., p. 572.

${ }^{10}$ Agradezco enormemente a la catedrática de Ciencias y Técnicas Historiográficas de la Universidad de Oviedo $\mathrm{M}^{\mathrm{a}}$ Josefa Sanz Fuentes la sugerencia del origen bávaro de Alejo de Vahía. 
lo y el de los escultores renanos ${ }^{11}$. El "apellido" "de Vahía" incita a pensar, como es frecuente en la época, en un topónimo. Joaquín Yarza dice desconocer lugar alguno centro o noreuropeo donde "Vahía" sea la transcripción castellana de un topónimo, por su parte C. Julia Ara aporta nuevos datos a este topónimo que, a nuestro juicio vienen a confirmar nuestra hipótesis ${ }^{12}$. Según esta autora, en la documentación de la catedral de Palencia se lee "Vahía" y en la del concejo de Becerril de Campos, donde tenía su residencia, aparece como "Vaya" o "Bayán". Pues bien, en cualquiera de los tres casos, la transcripción fonética coincide con la pronunciación en alemán de Baviera, es decir, Bayern, que equivaldría a [baian], sonido al que se asemejan tanto el "Vahía" como el "Vaya" y el "Bayán". Nos parece que la palabra "Vahía" ha estado durante mucho tiempo despistando a los investigadores por varios motivos: el primero, $y$ quizá más evidente, puede ser por la similitud con la palabra "bahía" que muy posiblemente haya llevado a acentuar la letra $i$; el segundo motivo puede ser el empleo de la grafía $v$ en lugar de la $b$ que realmente le correspondería en ese supuesto caso; si "Vahía" procediese de un topónimo escrito con $v$ el escultor alemán, al dar su nombre, quizá lo hubiera pronunciado como $/ \mathrm{f} /$.

La vinculación de Alejo de Vahía, (o Baviera), o en su defecto de personas de su círculo con Juan Arias del Villar procedería también de las etapas palentina y vallisoletana del obispo, sin olvidar el paso por la librería de la catedral de León de este taller. Alejo de Vahía está documentado en la provincia de Palencia ya hacia los años 80 del siglo XV y su trabajo en las ménsulas de la biblioteca del colegio de Santa Cruz de Valladolid se fecha entre 1487 y 1491, por lo tanto su carrera está, al igual que la de Bartolomé de Solórzano, en ciertos momentos unida a los distintos destinos de Juan Arias del Villar. Estas cuestiones, ya menciona-

\section{-}

${ }^{11}$ I. VANDEVIVERE, "L'intervention du sculpteur hispano - rhenan Alejo de Vahía dans le "Retable Mayor" de la Cathédrale de Palencia (1505)", Mélanges d'archéologie et $d$ ' histoire de l'art offers au Professeur Jacques Lavalleye, Lovaina, 1970, pp. 305-318.

12 J. YARZA LUACES, op. cit., p. 247 y C. J. ARA GIL, "Escultura en Castilla y León en la época de Gil de Siloe. Estado de la cuestión", Actas del Congreso Internacional sobre Gil de Siloe y la escultura de su época, Burgos, 2001, pp. $145-188$, especialmente p. 174. das por otros autores nos parecen suficientemente elocuentes.

Unidos a la obra de la sillería fueron otros ornamentos como las rejas de coro, los púlpitos los órganos y la portada del trascoro hoy trasladada a uno de los accesos a la Cámara Santa.

\section{LAS OBRAS}

En 1498 tuvo lugar el cierre de las naves bajo la dirección de Bartolomé de Solórzano, cierre que dio paso a las obras de la fachada. En 1500 se celebraron una serie de reuniones sobre la misma ${ }^{13}$. En una de ellas participaron los miembros del cabildo y los representantes del municipio para decidir el emplazamiento de la fachada torreada y su inserción en el urbanismo de la ciudad. En la otra se citaron los representantes del cabildo; Bartolomé de Solórzano, maestro de Oviedo y Palencia; el maestro de la iglesia de León, que a la sazón era Juan de Badajoz, el Viejo, y el maestro de la iglesia de Burgos, el único que no acudió.

Pilar García Cuetos opina que este maestro debía de ser Simón de Colonia, algo muy probable puesto que Simón estaba vinculado por línea paterna a las torres de la Catedral de Burgos, en las que se inspiran las de León ${ }^{14} \mathrm{y}$ además porque Burgos era un centro de referencia, en ese sentido se documentan al menos dos viajes de Pedro de Bueras, uno de ellos sin perjuicio de su sueldo, en relación con las obras de la torre de la catedral ${ }^{15}$.

\section{-}

${ }^{13}$ F. DE CASO FERNÁNDEZ, op. cit., pp. 339 - 340; M. P. GARCÍA CuETOS, op. cit., p. 567.

14 J. L. Blanco MozO, "La torre sur de la catedral de León. Del Maestro Jusquin a Hans de Colonia", Anuario del Departamento de Historia y Teoría del Arte, vol. XI, 1999, pp. 29 - 57. Blanco Mozo supone que el remate de la torre sur de la catedral de León puede ser obra de Juan de Colonia, a pesar de ciertas torpezas cometidas respecto a Burgos, por el paralelismo existente entre las agujas de ambas catedrales.

${ }^{15}$ M. P. GARCÍA CUETOS, op. cit., p. 567.

En 1510 Francisco de Caso documenta una visita a Burgos y en 1519 se dice en la documentación capitular que se ausentó veinte días. A estos viajes hay que añadir el realizado en 1520 a León donde estaba Juan de Badajoz, el Viejo. Para las visitas de 1519 y 1520 ver F. DE CASO FERNÁNDEZ, op. cit., p. 369. Para la visita de 1510 ver F. DE CASO FERNÁNDEZ, Colección documental sobre la catedral de Oviedo (1300-1550), Gijón, 1982, nº.150, p. 107. Anteriormente a estos tres viajes había hecho otro en 1505 también a Burgos, ver M. P. GARCÍA Cuetos, op. cit., p. 571. Nos interesa especialmente esta visita tan temprana, 
La documentada visita de Juan de Badajoz, el Viejo, junto con los representantes del cabildo al lugar sobre el que se iba a edificar llevó a Caso a pensar que en la reunión de maestros, éstos habían dado sobre la marcha trazas para la fachada torreada y al final se había elegido la propuesta de Juan de Badajoz frente a la del maestro titular; por esta razón visitaba con los miembros del cabildo el lugar en el que se iba a construir. De todo esto dedujo además que las trazas del frente de la catedral de Oviedo pertenecían a Juan de Badajoz y que desde ese momento, 1500, éste ocupa la maestría mayor de las obras ovetenses ${ }^{16}$.

Para esas dos reuniones celebradas en 1500 propone la doctora García Cuetos dos cuestiones: una de ellas es la del problema de la inserción de la fachada monumental que planeaba levantar el cabildo dentro de un espacio urbano de reducidas dimensiones, pues ocuparía una calle y parte del suelo perteneciente a la vecina parroquia de San Tirso, problema que se resolvió con la construcción de un pórtico perfectamente integrado en la red viaria urbana pues funcionaba a modo de calle porticada. Con respecto a la reunión de los maestros, acertadamente la interpreta como una reunión de maestros de reconocido prestigio ajenos a las obras ovetenses congregados para evaluar unas trazas ya dadas de antemano, ${ }^{17}$.

El presente artículo se centrará en el estudio del pórtico.

Waldo Merino y más adelante Francisco de Caso pusieron de manifiesto en su día la relación existente entre la librería de la catedral de León y el pórtico de la catedral de Oviedo ${ }^{18}$, relación que estaría justificada por la autoría común de Juan de Badajoz y por la contemporaneidad de las dos obras, levantadas en el entorno del 1500 .

La librería leonesa ha sido objeto de varios estudios centrados tanto en los aspectos

pues tiene lugar en los mismos años en los que se inician las obras del tramo sur del pórtico.

${ }^{16}$ F. DE CASO FERNÁNDEZ, La construcción de..., pp. 339- 347.

${ }^{17}$ Para todo lo referente a la posible autoría de estas trazas remito al trabajo de $\mathrm{M}^{\mathrm{a}}$ Pilar García Cuetos en esta misma revista.

${ }^{18}$ W. MERINO RUBIO, Arquitectura hispanoflamenca en León, León, 1974, pp. 99 - 170 y F. DE CASO FERNÁNDEZ, op. cit., p. 413. constructivos como los decorativos: además del trabajo citado de Waldo Merino, se cuenta con el publicado por Manuel Valdés Fernández, Concepción Cosmen Alonso y $\mathrm{M}^{\mathrm{a}}$ Victoria Herráez Ortega. Centrándose en el tema de la escultura, Angela Franco publicó una varia sobre la decoración secundaria en la catedral de León bajo el maestrazgo de Juan de Badajoz, el Viejo y recientemente Eduardo Carrero ha revisado todas estas cuestiones. ${ }^{19}$

Con respecto a la obra de la librería en sí, se puede decir que era un proyecto previsto desde 1478 que no se materializó hasta los primeros años de la década de los 90. La orden para el inicio de las obras aparece en la documentación capitular en 1492. Entre 1501 y 1504 se construyó la puerta que comunica la librería con una de las capillas de la cabecera, tal y como se deduce de la presencia allí del escudo del Cardenal Desprats, obispo de León en aquellos años. La contratación de las vidrieras en 1505 con Diego de Santillana permite suponer que la obra arquitectónica estaba concluida.

La puerta que comunica la librería con la capilla de San Andrés se abrió entre 1525 y 1530 aproximadamente, con diseño y dirección de Juan de Badajoz, el Mozo, en el lugar en el que su padre había trazado un arco conopial $\operatorname{ciego}^{20}$.

-

${ }^{19}$ M. VAldÉs FernándeZ, C. COSMEn AlOnso, M. V. Herráez Ortega, "La Edad Media. Del origen a la consolidación de un templo gótico", Una historia arquitectónica de la Catedral de León. León, 1994, pp. 13 - 131, especialmente pp. 128 - 169; A. FRANCO MATA, "Elementos decorativos secundarios en la Catedral de León a finales del siglo XV y comienzos del XVI durante el maestrazgo de Juan de Badajoz "el Viejo"”, Archivo Español de Arte, 200, 1977, pp. 417 - 422; E. CARRERO SANTAMARÍA, op. cit., pp. 298 298, y Santa María de Regla de León. La catedral medieval y sus alrededores, León, 2004, pp. 93 - 104. También en J. M. VillanUeVA LÁzARO, La ciudad de León: el gótico. León, 1986; A. FRANCO MATA, Escultura gótica en León y provincia (1230-1530), León, 1998; M. VALDÉS FERNÁNDeZ, M. V. Herráez OrtegA, C. Cosmen Alonso, Monografías de Historia y Arte: El arte gótico en la provincia de León, León, 2001, pp. 50 - 103; M. D. TEIJEIRA PABLOS, "La última escultura gótica. Las obras del siglo XV", La Catedral de León en La Edad Media, León, 2004, pp. 381397; M. VALDÉS FERNÁNDEZ, "Promotores, arquitectos y talleres en el ocaso de la Edad Media", La catedral de León en la Edad Media, León, 2004, pp. 367-380, especialmente $379-380$.

${ }^{20}$ W. MERINO RUBIO, op. cit. pp. 99-170; M. VALDÉS FERnÁNDEZ, C. COSMEN AlONSO, M. V. HERRÁEZ ORTEGA, op. cit., pp. 128 - 131; M. D. CAMPOS SÁNCHEZBORDONA, "La Edad Moderna. Las transformaciones del 
Parece haber quedado demostrado que los autores de las primeras trazas de la librería no fueron, como pensaba W. Merino, los hermanos Rodrigo y Juan de Badajoz, ya que estos llegaron a la obra en 1498 y 1499 respectivamente. En el momento de la llegada de Juan de Badajoz el debate se centraba en la cuestión, denunciada además de por Badajoz por el oficial Pedro de Bueras, de la escasa altura de la que debían arrancar las bóvedas. Sería pues Juan de Badajoz, el Viejo, quien diseñara los nervios que, partiendo de las ménsulas, llegan hasta los capiteles de mocárabes de los cuales arrancan las bóvedas que cubren los tres tramos de la librería $^{21}$. Dos son los repertorios escultóricos a destacar: el más importante, dado el mensaje que recoge, es el de las ménsulas; el otro es el que, a modo de decoración marginal, recorre la línea de imposta y la puerta de ingreso desde una de las capillas de la cabecera.

El programa recogido en las ménsulas fue analizado en su día por varios autores ${ }^{22}$, actualmente se cuenta con la revisión del mismo por Eduardo Carrero ${ }^{23}$.

Waldo Merino y Angela Franco atribuyeron la escultura de las ménsulas a Badajoz, hipótesis desmontada definitivamente por Eduardo Carrero cuando estableció la intervención de Badajoz en el cambio de proyecto que partió precisamente de las ménsulas. Previamente Julia Ara y Joaquín Yarza habían puesto en duda tal autoría al creer, respectivamente, que eran obra de Alejo de Vahía o de alguien de su círculo. Eduardo Carrero comparte la opinión de Joaquín Yarza y considera que el escultor responsable de dichas tallas era alguien vinculado al taller de Alejo de Vahía.

renacimiento y el esplendor barroco", Una historia arquitectónica de la catedral de León, León, 1994. pp. 138 - 139; E. CARRERO SANTAMARÍA, "Una alegoría y un sarcasmo...", pp. 289 - 291 y Santa María de Regla de León..., pp. 93 98.

${ }^{21}$ E. CARRERo Santamaría, "Una alegoría y un sarcasmo..." pp. 290 - 291 y Santa María de Regla de León...p. 96. Este autor al imaginar una librería cubierta con arcos fajones a partir de las ménsulas encuentra parecidos con la sacristía de la catedral construida por Alfonso Ramos, maestro mayor hasta poco antes del comienzo de las obras de la librería, cuyas trazas, tal y como se deduce de la documentación capitular, ya estaban dadas antes de 1492.

${ }^{22}$ W. MERINO RuBIO, op. cit., pp. 136-139 y A. FRANCO MATA, op. cit., pp. 417 - 422.

${ }^{23}$ E. CARRERO SANTAMARÍA, "Una alegoría y un sarcasmo..." y Santa Maria de Regla de León... pp. 97 - 104.
En cualquier caso, siguen modelos que hemos localizado en la costa atlántica francesa durante el trabajo de la tesis doctoral en la que se enmarca esta publicación, pudiendo citarse los casos de Saint Pierre de Saintes (CharenteMaritime) o la capilla de Notre - Dame de la Rose de Saint - Seurin de Burdeos (La Gironda).

Los modelos iconográficos aquí empleados proceden de repertorios versátiles y por su morfología susceptibles de ser utilizados en obras diversas. Así, han aparecido personajes en la misma posición que los de estas ménsulas en las misericordias de sillerías corales. Para el caso de sillerías españolas, Isabel Mateo recogió alguno de estos ejemplos, pero nos ha parecido sorprendente la cantidad de sillerías francesas que emplean este tipo de repertorios ${ }^{24}$. Para el caso de Francia, en el corpus de misericordias medievales de la doctora Elaine Block ${ }^{25}$, seis imágenes de personajes, -ángeles, profetas y clérigos-, parecen sostener la misericordia del mismo modo que los que se tallaron en las ménsulas de la librería. No obstante, más que la identificación de estos personajes lo que resulta significativo es la tipología, la adaptación de estos repertorios iconográficos a espacios claramente diferenciados.

Waldo Merino y Ángela Franco supusieron que la decoración de cardinas, putti y animales fantásticos recogía una iconografía relacionada con los vicios y ésta, a su vez, guardaba relación con el repertorio desarrollado en las ménsulas. Posteriormente se ha desestimado esa supuesta relación ${ }^{26}$. No se puede, por el momento, saber si realmente con esta decoración se pretendía transmitir un mensaje concreto, puesto que es posible que al proceder de un repertorio utilizado con frecuencia simplemente se limite a una función decorativa. Los mismos motivos

-

24 I. MATEO GÓMEZ, Temas profanos en la escultura gótica española. Las sillerías de coro, Madrid, 1979, lámina XIX, fig. 90.; lámina XXXVIII, fig, 166; lámina LVIII, figs. 277 y 278, y E. C. BLOCK, Corpus of medieval misericords in France. XIII - XVI century, Turnhout, 2003, pp. 257, 281, 283, 301, 303, 323, 345, 366, 385, 389, 396 y 436.

${ }^{25}$ Los ángeles tenantes esculpidos en ménsulas son un motivo muy habitual en el arte centroeuropeo de estos momentos. La tipología empleada en la librería de la catedral de León es la más habitual, pero resulta curiosa la que emplea Juan de Badajoz, el Viejo, en la cabecera de San Isidoro de León, dónde los ángeles situados bajo la línea de imposta están en posición erguida.

${ }^{26}$ E. CARRERo SANTAMARÍA, "Una alegoría y un sarcasmo..." y Santa María de Regla de León... pp. 101 - 103. 
aparecen en sillerías corales, márgenes miniados de libros y como se verá más adelante, aparecen en Asturias decorando arquitecturas de carácter diferenciado.

Es en los baquetones que parten de las ménsulas, los capiteles de mocárabes y los abovedamientos, además de en la decoración escultórica, donde se observan los estilemas que Juan de Badajoz repite en el pórtico de la catedral de Oviedo. Con toda la información sobre ambas obras: librería y pórtico, puede continuarse el estudio de la obra ovetense (Imagen 1).

Compartimos la idea de la doctora García Cuetos de las siguientes autorías y fases del pórtico: la traza del mismo podría no corresponder íntegramente a Juan de Badajoz, el Viejo. Sino que partiría del modelo dado por Bar y Bauselas. Es posible que la idea inicial, que no tiene porqué ser la definitiva y que debió de basarse en la de la fachada armónica como era habitual en la época, fuese también modificada por Bartolomé de Solórzano, pues no consta que en 1500 se le desvinculase de las obras. Cuando en 1498 Juan Arias del Villar fue trasladado a la diócesis de Segovia, el cabildo no rompió su relación con el maestro mayor de obras a pesar de que el templo ya se había cerrado. El impás de dos años que se produjo en las obras pudo deberse, como opina Caso, a una ornamentación del interior del templo ${ }^{27}$, pero además existía el problema de la falta de espacio para la fachada y la necesidad de una planificación tanto de dicha fachada como del terreno sobre el que se iba a levantar ${ }^{28}$. El papel que debió desempeñar Juan de Badajoz, el Viejo, en la mencionada reunión debió de ser el de perito y sus sugerencias debieron de ser valoradas por el cabildo, razón por la que quizá le contrataron años después.

La primera aparición documental de Badajoz como maestro mayor de la catedral de Oviedo tiene lugar en 1505, momento en el que se supone se terminó la labor arquitectónica de la librería de León ${ }^{29}$. En 1500, como ya se ha

${ }^{27}$ F. DE CASO FERNÁNDEZ, op. cit., pp. 339 -340.

${ }^{28}$ M. P. GARCía CuETOS, "Entre la civitas y la urbs...", pp. 106-119, y "Juan de Badajoz, el Viejo, entre Oviedo y León...", pp. 566-567.

${ }^{29}$ El oficial Pedro de Bueras que ya aparece en la documentación referente a la librería leonesa durante la presencia allí de Juan de Badajoz, trabajó más tarde en el pórtico de Oviedo como aparejador. Francisco de Caso le dicho, no consta en ningún documento que se le haya dado la maestría mayor de las obras, del mismo modo que no consta el cese en tal cargo de Bartolomé de Solórzano, del cual únicamente sabemos que en ese momento se ausentó de las obras y que realizó dos visitas a la ciudad en 1502 y 1504 . Anterior a 1502 fue el arranque del tramo norte del pórtico, tal y como se deduce del escudo del obispo Juan Daza, trasladado en 1502 a Cartagena. Por lo tanto, y teniendo en cuenta lo apuntado hasta aquí, el tramo norte fue iniciado en los supuestos dos últimos años de la maestría de Solórzano ${ }^{30}$.

De este tramo norte, estructuralmente es destacable la puerta enviajada que, en el cierre septentrional, comunica el pórtico con la calle Gascona. Su despiece habla de un maestro que domina perfectamente el corte de la piedra, pudiera ser Bartolomé de Solórzano.

Nuestra hipótesis sobre la construcción de este tramo del pórtico es la siguiente: parece claro que en ella trabajaron dos maestros distintos, por un lado proponemos una intervención inicial bajo la maestría de Bartolomé de Solórzano y una segunda intervención bajo la maestría de Juan de Badajoz, el Viejo, que quizá se desarrollase bajo la dirección de su aparejador Pedro de Bueras, dadas las continuas ausencias de la fábrica del maestro titular. La fase correspondiente a Solórzano tuvo que iniciarse poco después de la ya mencionada reunión de maestros de 1500 y debió terminar hacia 1502. A tenor de lo que se puede observar actualmente, su labor debió de ceñirse a los muros perimetrales, aproximadamente hasta la altura de la línea de imposta que al alcanzar la rosca del arco de acceso occidental, lo trasdosa y desemboca en la macolla. Para esta interpretación me he basado en la presencia del escudo del obispo Juan Daza, (1498 - 1502), situado bajo la mencionada imposta y que, según la documentación manejada por Francisco de Caso, fue mandado colocar allí en $1502^{31}$. Con respecto a los contrafuertes noroccidentales que debían contrarrestar los

encuentra mencionado por primera vez en la documentación ovetense en 1505 con motivo de una revisión de su contrato, por lo que deduce que al menos desde 1504, si no antes, se encontraba en la fábrica asturiana. Puede suponerse que llegó junto a Juan de Badajoz, el Viejo; sería lo más lógico y esta cronología apoya la hipótesis de que Badajoz recibiese la maestría mayor hacia 1502 o como muy tarde en 1504 .

${ }^{30}$ M. P. GARCÍA CuETOS, op. cit., pp. 569-570.

${ }^{31}$ F. DE CASO FERNÁNDEZ, op. cit., p. 444. 
empujes de la torre, ya Pilar García Cuetos llamó la atención sobre la diferencia de su tratamiento con respecto a los que se levantan en frente. Los noroccidentales presentan el fuste alabeado y se decoran con unos arquillos entrelazados, mientras que los otros reciben un cajeado y unas molduras rectangulares, giradas $45^{\circ}$, rompen la ascensionalidad a la altura de los arquillos entrelazados. Es posible que los pilares de fuste alabeado pertenezcan a la labor de Solórzano mientras que los otros sean obra de Badajoz.

La fase correspondiente a Badajoz se iniciaría a partir de 1502 y terminaría, para este tramo, antes de 1508, pues en la parte superior del muro aparecen las armas del obispo García Ramírez de Villaescusa, $\left(1502\right.$ - 1508) ${ }^{32}$. Comprendería la parte del muro que está por encima del arco occidental y en ella debería incluirse la línea de imposta decorada con bolas. Esta línea de imposta ha sido atribuida por Francisco de Caso a Badajoz por la similitud con la que decora el exterior de la cabecera de San Isidoro de León, construida por éste a partir de $1515^{33}$; Pilar García Cuetos consideró esta moldura más propia de Solórzano. A nuestro juicio, y reconociendo que es un elemento decorativo muy propio de la saga de los Solórzano, presentando los contrafuertes cajeados similitudes con los de la cabecera de San Isidoro de León y teniendo en cuenta las cronologías que nos inspira la heráldica pensamos que podría atribuirse a Juan de Badajoz, el Viejo.

Apoyando todo esto estaría también la presencia de la bóveda, inspirada en la de la librería de León, cuyos terceletes arrancan de los jarjamentos que surgen de los capiteles de mocárabes situados más o menos a la misma altura de la fase perteneciente al episcopado de García Ramírez de Villaescusa.

Con respecto a las ya comentadas diferencias existentes entre los machones del tramo norte y los restantes, es preciso señalar que el planteamiento general del basamento es unita-

-

32 Pienso que pudo terminarse antes de 1508 porque en 1507 hubo una reunión para ajustar cuentas con la parroquia de San Tirso ya que se estaba comenzando a planificar el desarrollo de la torre sur y se había ocupado suelo de la parroquia. Posiblemente la ocupación de este terreno haya tenido lugar desde el inicio de las obras del pórtico, es decir, desde el entorno del 1500 con un encintado del solar.

${ }^{33}$ F. DE CASO FERNÁNDEZ, op. cit., p. 444. rio. A partir de los trabajos realizados dentro del Plan Director de la catedral, se ha publicado un ejemplar estudio planimétrico de todas las dependencias catedralicias a cargo de los arquitectos Jorge Hevia y Cosme Cuenca ${ }^{34}$. En las planimetrías levantadas para la planta del pórtico y las bóvedas se aprecia de modo claro que el trazado interior de las basas del tramo norte, las del extremo septentrional y las que separan el tramo norte del central-, dibujan una curva con un leve apuntamiento en el centro frente a las restantes que presentan un trazado más apuntado. Al exterior las diferencias se aprecian en los fustes ya comentados más que en los basamentos.

La bóveda del tramo norte es la que más similitudes presenta con las de la librería de León, cuestión analizada ya por Caso ${ }^{35}$. De hecho es prácticamente idéntica, ambas son bóvedas de terceletes y cinco claves cuyos nervios diagonales pasan por la clave mayor. Los terceletes llegan hasta las claves secundarias, los combados rectos unen la clave mayor con las secundarias, (en León llegan hasta las claves de perpiaños y formeros, siendo esta la única diferencia entre las dos bóvedas), los combados curvos dibujan un pétalo apuntado desde el nervio central de los terceletes hasta la clave de formeros y perpiaños. Las similitudes de esta bóveda con la contemporánea de la librería leonesa, que se construyó entre 1499 y 1505, lleva a pensar que de las tres bóvedas del pórtico es la más vinculada a Juan de Badajoz, el Viejo $^{36}$ (Imagen 2).

La noticia documental de 1505 recogida por Caso en la que se habla del suministro de piedra y herramienta para la obra es interpretada

${ }^{34}$ F. DE CAso Fernández, C. Cuenca, C. García de Castro, J. Hevia, V. de la Madrid, G. Ramallo, R. Tolín, La catedral de Oviedo. I. Historia y restauración. Oviedo, 1999, p. 121. Más recientemente ha salido a la luz una publicación referente a las obras de restauración en el claustro y torre de la catedral: F. DE CASO FERNÁNDEZ, C. Cuenca Busto, R. M. Esbert Alemany, C. García de Castro Valdés, J. Hevia Blanco, V. De la Madrid Álvarez, P. Paniagua Félix, J. Puras Higueras, S. Ríos GONZÁLEZ, L. VALDEÓN MENÉNDEZ, La restauración de la torre y el claustro de la catedral de Oviedo, Oviedo, 2004. Se trata el tema de la historia de la torre en las páginas 37 y 44 - 64, especialmente 44 - 45.

${ }^{35}$ F. DE CASO FERNÁNDEZ, op. cit., p. 446.

${ }^{36}$ Esta bóveda debió trazarla la mano del maestro Badajoz, las otras dos bóvedas del pórtico, aunque dependientes del estilo badajociano y de la librería leonesa, pueden pertenecer a Pedro de Bueras. 
como un abastecimiento de materiales para la construcción de la torre sur. En la misma línea interpreta la reunión que en 1507 mantuvo el cabildo con el regimiento y la parroquia de San Tirso para saldar la deuda contraída al ocupar suelo pertenenciente a la parroquia. La expresión "que se ha de pagar por lo que la iglesia tomó para asyento de la torre del Portal a San Tirso" ha de interpretarse como que para entonces el suelo ya estaba ocupado. La presencia de las armas de Valeriano Ordóñez de Villaquirán, (1508 - 1512), establece el fin de las obras del primer cuerpo de la torre, es decir del tramo sur, hacia $1512^{37}$.

Entre esos años, 1505 y 1512, tuvieron lugar varios hechos significativos: por un lado el cambio de maestro mayor de obras en 1511 cuando debido a sus continuas ausencias fue cesado Juan de Badajoz, el Viejo, y ocupó su cargo su aparejador Pedro de Bueras, que por otra parte ejercía como tal en las ausencias de su superior. Por otro lado se documentan una serie de viajes de Pedro de Bueras que nos orientan sobre cuáles eran los referentes de la fábrica catedralicia ovetense: en 1505, año en el que se supone comenzó a llegar el material para la torre, Bueras viaja a Burgos ${ }^{38}$; en 1510 regresó a la ciudad castellana y se deja claro que realiza el viaje sin detrimento de su salario, aclaración significativa de que viaja a resolver alguna cuestión relacionada con su labor en la catedral; Francisco de Caso recoge la noticia documental de otro viaje en 1519 aunque no aclara a dónde va y finalmente en 1520 se sabe que viajó a León $^{39}$. Estos viajes demuestran, una vez más, la dependencia que la fábrica ovetense tiene tanto de Burgos como de León; Bueras viajó a Burgos el mismo año en que suponemos se inició el tramo sur que es a la vez arranque de la torre, ¿cuál fue el motivo de su viaje?, sabemos que su vinculación a dicha sede venía desde el momento de su formación, pues así lo alega en el momento de justificar su hidalguía ${ }^{40}$. Su aprendizaje tuvo que tener lugar en el círculo de Simón de Colonia, maestro de prestigio más que recono-

-

${ }^{37}$ F. DE CASO FERNÁNDEZ, op. cit., pp. 347 - 351.

${ }^{38}$ M. P. GARCía CUETOS, op. cit., p. 571.

${ }^{39}$ F. DE CASO FERnÁNDEZ, op. cit., p. 369.

${ }^{40}$ M. P. García Cuetos, op. cit., p. 571. Para todo lo referente a la personalidad de Pedro de Bueras y su trabajo en Oviedo ver el trabajo de la doctora García Cuetos Arquitectura en Asturias. 1500 -1580. La dinastía de los Cerecedo. Oviedo, 1996. cido por aquel entonces y al que en 1500 suponemos convocó el cabildo ovetense para la discusión acerca de la fachada. No sería arriesgado pensar que Bueras hubiese viajado entonces al lugar en el que se había formado a pedir opinión sobre el modo más conveniente de levantar el cuerpo bajo "vacío" de una torre de considerable envergadura. Los viajes realizados en 1519 y 1520 estarían vinculados a cuestiones relativas al cuerpo de la torre, si se acepta la cronología propuesta de 1512 como finalización del cuerpo bajo.

En cuanto a la cubierta, se mantienen las características ya comentadas en el tramo norte de bóveda de terceletes apoyada en ménsulas de mocárabes. El abovedamiento no copia literalmente ninguno de los tramos de la librería leonesa pero se inspira en uno de ellos. Aquí nos encontramos con una bóveda estrellada en la que el espacio destinado a la clave central queda libre dentro de un rombo inscrito en una estrella surgida de la bifurcación del nervio central de los terceletes. Se parte pues, de la idea de la bóveda estrellada del tramo meridional de la librería de León pero complicándola con la multiplicación del motivo principal (Imagen 3).

El tramo central debió iniciarse a mediados de la segunda década del siglo XVI. El maestro mayor continuó siendo Pedro de Bueras, que ocupó el cargo hasta el año 1530 en que muere. En esta tercera fase del pórtico se mantienen las características generales del mismo, puesto que se continuó empleando el mismo tipo de basamentos, la misma decoración de las portadas y por supuesto los capiteles de mocárabes de los que arrancan los nervios entrecruzados que conforman la bóveda (Imagen 4). Ésta, está inspirada en la bóveda del tramo central de la librería leonesa, aunque al cubrir un espacio mayor presenta una mayor complejidad con la bifurcación de los nervios exteriores de los terceletes que trazan pequeños rombos que unen las claves de los arcos formeros y perpiaños con los motivos geométricos centrales. Por lo demás el esquema de la bóveda leonesa se repite en el trazado de un rectángulo central con un rombo inscrito dividido por las ligaduras en cuatro partes decoradas con tracerías ciegas

Las obras de este tramo se paralizaron a raíz del incendio que la noche de Navidad de 1521 arrasó buena parte de la ciudad. Si bien es 
cierto que la catedral debió de verse escasamente perjudicada por el fuego ${ }^{41}$, las casas arrendadas que el cabildo tenía en la ciudad sufrieron las consecuencias. Con ellas desaparecían también los ingresos de un dinero destinado a la financiación de las obras ${ }^{42}$. Lo más urgente era pues la reconstrucción de dichas casas. Francisco de Caso estima que las obras en la catedral debieron retomarse hacia 1524 - 1526, en esos momentos se documentan pagos a canteros por el suministro de material para la "lonxa y torre" de la catedral, entendiendo por lonja el pórti$\mathrm{co}^{43}$. El final de las obras de este tramo no está muy claro, Francisco de Caso considera que debió de terminarse hacia 1527, pues en ese momento se documenta la llegada de teja para la lonja, centrándose en las portadas el trabajo del año $1528^{44}$. Sin embargo, el mismo autor localiza pagos a canteros que en 1528 y hasta el mes de enero de 1529 trabajaron "en la lonxa",45. El 24 de enero de 1532 se encarga al administrador de la fábrica que "tenga cargo de vesytar la longa (sic) contino se apuntar los / que faltaren algunas oras como se solia hazer, y la ora que faltare cada uno / se la descuente en cabo el

${ }^{41}$ M. P. García Cuetos, op.cit., pp. 99 - 105, y "Oviedo (España). Poder religioso y poder civil en el trazado de la ciudad medieval", Centre. Region. Peryphery. Medieval Europe. Bassel, 2002, Volume 2, Sections 4 and 5, Hertingen, 2002, pp. $114-119$. Según esta autora, la ciudad contaría en el momento del incendio con una muralla interior que separaría los dos ámbitos de la ciudad de Oviedo, la civitas episcopal de la urbs burguesa. Al iniciarse el incendio en un horno de pan en el ámbito burgués, el fuego destruyó la mayor parte de esa zona de la ciudad y la muralla que delimitaría la jurisdicción episcopal actuaría a modo de cortafuegos, de modo que solo se vio ligeramente afectado una parte del andamio de la torre que en ese momento estaba en construcción.

42 Sobre la financiación de las obras tras el incendio de 1521 ver C. LABRA GONZÁlEZ, "La obra y fábrica de la catedral de Oviedo tras el incendio de 1521. Documentos referentes a las dificultades económicas", Studium ovetense. Homenaje a don Raul Arias del Valle, (en prensa). Acerca de esta cuestión continúo trabajando en la actualidad.

${ }^{43}$ F. DE CASO FERNÁNDEZ, op. cit., pp. $369-377$.

${ }^{44}$ F. DE CASO FERNÁNDEZ, op. cit., pp. 376 - 377. Remite el autor al documento número $221 \mathrm{del}$ segundo volumen de la Colección documental sobre la Catedral de Oviedo..., pero el documento no menciona las portadas: "Salarios del año de veynte e ocho. Pague al maestro de la obra diez mill maravedis que se le dan de maestro, los / quales se le dan de salario allende los jornales. Yten pague a Zereçerdo tres castellanos que se le dan de salario allende / los jornales, que son mill e quatroçientos e çinquenta e çinco maravedis."

${ }^{45}$ F. DE CASO FERnÁNDEZ, Colección documental..., pp. $84-92,105-106, \mathrm{n}^{\circ} 222,227$. mes ${ }^{, 46}$. Al menos hasta 1535 había obreros en la lonja, tal y como se deduce del siguiente texto: "Çesar obras. El señor licenciado Diego Perez, provisor, e los dichos señores acordaron e mandaron que por la grand / neçessidad que la presente tiene la fabrica e poca necesidad de obras de canteria que se / despidiesen a todos los offiçiales de la lonja e non labrasen mas..." ${ }^{, 47}$. Estos trabajos en el pórtico hasta la avanzada fecha de 1535 ¿deben asociarse con la ornamentación escultórica o se refieren aún a aspectos arquitectónicos?

Las planimetrías levantadas para las bóvedas muestran de un modo más evidente lo que se puede apreciar a simple vista: ninguno de los arcos presenta el mismo trazado ni el mismo número de arquivoltas y las diferencias entre los de un tramo con respecto a los otros dos son claras. En el caso del arco que separa el tramo septentrional del central las claves de las arquivoltas no se encuentran alineadas a consecuencia de un error de cálculo que repercute en el trazado de las bóvedas, pues los combados que conforman la tetrapétala apuntada tienen que forzarse en este punto para hacerlos coincidir con la clave del arco (Imagen 2).

La bóveda meridional ha sido ejecutada de modo impecable y no hay en ella ninguna corrección a diferencia de lo que sucede en la última de las construidas (Imagen 3). En el tramo central, cuyo espacio se vería condicionado por los dos cuerpos adyacentes, se diseñaron unos rombos surgidos de la bifurcación de los terceletes cuyos vértices coinciden con las claves de los arcos perpiaños que separan los tra$\operatorname{mos}^{48}$ (Imagen 4).

La similitud que presentan las tracerías de las tres portadas que dan acceso a cada una de las naves del pórtico es uno de los argumentos empleados a la hora de defender la idea de la unidad estilística que se pretendió mantener durante todo el proceso constructivo del transepto y las naves a pesar de los años transcurridos. Francisco de Caso opina que la inspiración de los mismos parte de la tracería de la portada

\footnotetext{
46 Ídem, p. 120, nº 244.

${ }^{47}$ Ídem, p. 125, no 253.

${ }^{48}$ F. DE CASo Fernández, C. CuencA, C. García dE Castro, J. Hevia, V. de la Madrid, G. Ramallo, R. TOLíN, op. cit., p. 121.
} 
de la capilla del Rey Casto ${ }^{49}$, por aquel entonces puerta septentrional del transepto.

De las tres portadas, la que más relación mantiene con ella es la central. En este caso el acceso al interior se realiza a través de dos arcos carpaneles cobijados bajo un arco apuntado de dos arquivoltas en las que se sitúan las repisas y doseletes que, al igual que el parteluz, debían albergar imágenes.

El motivo que caracteriza a la portada del Rey Casto es la tracería calada del tímpano, motivo que de manera más significativa pone en evidencia la relación existente entre la puerta de la nave central y la anterior. La idea es la misma, del centro parten dos nervios curvos que se van separando a medida que ascienden y dividen el espacio en tres zonas, decoradas en el caso de la puerta más antigua con motivos fusiformes distintos que dotan a la portada de una asimetría de la que carece la portada central de la fachada, pues repite en ambos lados el motivo del lado izquierdo de la portada del transepto.

Las diferencias más significativas se encuentran en los basamentos y la decoración del extradós del arco. Los contrafuertes que flanquean esta portada son el rasgo más característico del lenguaje de Badajoz, el Viejo.

El trazado de las portadas laterales es muy similar. En ambas encontramos, flanqueada por contrafuertes, una puerta en arco carpanel cobijada por un arco apuntado para cuyo tímpano se diseñó una tracería calada muy similar, con la única diferencia del motivo central. Aunque a simple vista parecen iguales hay entre ambas diferencias evidentes. La septentrional presenta un arco carpanel más deprimido que la meridional, las arquivoltas del arco apuntado no son tan anchas como las del lado sur y en lugar de dos arquivoltas con ménsulas y doseletes únicamente se disponen estos elementos en una de ellas.

En el cierre de las naves, situado por encima de las portadas, se optó en cada uno de los casos por soluciones diferentes: en la portada norte se dispuso un arco mixtilíneo idéntico en trazas y decoración al que Juan de Badajoz, el Viejo, situó en el muro occidental de la librería de León y bajo el que más tarde su hijo abrió un

\footnotetext{
${ }^{49}$ F. DE CASO FERNÁNDEZ, La construcción de..., pp. $415-432$
}

gran arco carpanel para establecer comunicación con la capilla de San Andrés (Imagen 5). El muro de la portada meridional se decoró con nueve ménsulas con sus respectivos doseletes para recibir unas esculturas que nunca llegaron a colocarse $^{50}$ (Imagen 6).

El repertorio decorativo desplegado en las arquivoltas del pórtico y en las de las tres portadas, responde al programa utilizado por Juan de Badajoz, el Viejo, en sus obras en la catedral leonesa, tanto en la librería como en la Portada del Cardo. Consiste en el ya mencionado repertorio de hojas de cardo entre las que se disponen putti, animales y seres fantásticos. No se repiten de manera sistemática los mismos motivos, hemos observado en León mayor riqueza iconográfica y una mayor calidad, cuestión esta última que quizá pueda deberse al deterioro al que están expuestos los motivos ovetenses. En Oviedo proliferan mucho más que en León los hombrecillos desnudos en distintas actitudes y se puede ver la evolución estilística del mismo motivo a lo largo de las tres grandes fases del pórtico (Imágenes 7 y 8). En el tramo norte la talla es muy similar a la de León, sobre todo en el caso de la puerta de acceso a la nave, no se debe olvidar que cronológicamente esta fase es la más próxima a la obra leonesa. La calidad del trabajo de la portada de la Cámara Santa está bastante próxima a esta fase del pórtico a pesar de que está fechada entre 1508 y 1512 por encontrarse en ella las armas del obispo Valeriano Ordóñez de Villaquirán. Esta portada sería pues contemporánea a la construcción del tramo sur del pórtico aunque en la decoración de éste, a nuestro juicio, trabaja un taller diferente, pues la estética está más próxima a la del renacimiento. La evolución definitiva de estos motivos se encuentra en el tramo central del pórtico donde a los escultores les cuesta repetir con la misma naturalidad el motivo de la hoja de cardo que dominan los del tramo norte y los putti presentan un tratamiento corporal más clasicista.

De todo esto se puede deducir que para la escultura del pórtico se estableció en su día un programa típicamente tardogótico basado en los repertorios ya mencionados para la librería

\footnotetext{
${ }^{50}$ Suponemos que la solución adoptada para el mismo espacio en el caso de la portada central debió de ser similar a los descritos y que sería sustituido por el relieve de la Transfiguración, de época moderna, que se puede ver actualmente.
} 
de León de hojas de cardo, hombrecillos desnudos y seres fantásticos. Al igual que sucedió en el aspecto arquitectónico, en el que siempre se mantuvieron los planteamientos generales, en el caso de la escultura se decidió emplear una serie de motivos que en esos momentos empezaban a ser sustituidos por los clasicistas. Lo mismo sucedería con la estética: en la segunda y tercera década del siglo XVI comienza a abrirse paso la renacentista. Los talleres que trabajan en el pórtico catedralicio se encuentran, y así lo reflejan, en ese periodo transicional.

Las decoraciones con arcos de cinco centros que se emplearon para decorar los paños situados por encima de los accesos a las naves se encuentran dentro del repertorio de formas empleado por Juan de Badajoz, el Viejo, en la librería de León. Las ligeras diferencias que presentan entre sí son indicativas, por un lado, de las distintas fases constructivas, por otro, de la distinta autoría. En el tramo norte, donde se puede considerar que estuvo más implicado Badajoz, el arco del exterior es en todo semejante al que se ubicó en el lugar donde se tenía pensado abrir un vano de comunicación con la capilla de San Andrés en la librería de León, tanto su trazado como los motivos que lo decoran se repiten en lo que conforma la decoración superior de una puerta ${ }^{51}$. Se trata de un arco de cinco centros que se completa en el centro con un conopio, rematado todo ello con cardinas y macolla cruciforme central y decorado en la rosca con hojas de cardo. El arco interior parte del esquema del exterior, es también un arco de cinco centros, pero carece del remate conopial. En su lugar se dispuso una repisa con su correspondiente chambrana. Aquí la decoración de hojas de cardo parece corresponder a artífices distintos a los que trabajaron en la parte exterior.

En el acceso a la nave sur, al exterior se sustituyeron las arcuaciones por un conjunto de nueve repisas con doselete para recibir esculturas. Francisco de Caso reseña las similitudes que los doseles de los extremos presentan en el trazado de los arcos con las chambranas que Juan de Badajoz, el Viejo, situó en el testero de la librería leonesa ${ }^{52}$ (Imagen 6). Al interior, se

\section{-}

${ }^{51}$ Es aquí además, como se acaba de comentar, donde los motivos decorativos guardan más similitudes con la obra leonesa.

${ }^{52}$ F. DE CASO FERNÁNDEZ, op. cit., p. 429. El comentario lo toma de W. MERINO RUBIO, op. cit., p. 124. trazó un arco que se puede considerar síntesis de los dos arcos de la portada septentrional ${ }^{53}$. Aquí se combina el arco de cinco puntas del interior del acceso norte con el conopio del arco exterior, completado con una línea de imposta que discurre por el centro de los arcos. En los vértices de los arcos que hacen contacto con la imposta se tallaron repisas caladas con doble florón ${ }^{54}$.

En la talla de los motivos ornamentales creemos ver tres manos distintas, muy similares a las que realizan la portada norte.

Al hilo de estas observaciones sobre la evolución estética que se aprecia en cada uno de los tramos del pórtico no quisiéramos terminar sin haber mencionado las ménsulas que se tallan en las jambas de cada una de las puertas por el exterior y que son susceptibles de ser comparadas con las obras de las que se hablará para finalizar este estudio. En el caso del tramo norte, las ménsulas, que apoyan en pilares, reciben una decoración a base de hojas de cardo cuya talla se aprecia con dificultad debido al deterioro. En la siguiente fase constructiva las ménsulas apoyan sobre un pilar mucho más fino y la superficie esculpida es mucho mayor, las hojas de cardo han sido talladas con gran detallismo y son de muy buena calidad. La tipología varía para las ménsulas del tramo central. Aquí el espacio que recibe la decoración es mucho más amplio y se va ensanchando a medida que se asciende. En las dos superficies inferiores se talló un motivo vegetal en la línea de la decoración de todo el conjunto, mientras que para la parte superior se intenta recrear el motivo arquitectónico de un pórtico, en un caso conformado por arcos de medio punto, en otro por una estructura adintelada, ambos de inspiración clasicista.

Buena parte de los aspectos constructivos y del repertorio ornamental desplegado en la catedral de Oviedo en estos momentos se han situado a medio camino, tanto estilística como cronológicamente, entre la librería de León y la Portada del Cardo; mostrando la evolución del

\footnotetext{
${ }^{53}$ F. DE CASO FERNÁNDEZ, op. cit., p. 429.

${ }^{54}$ F. DE CASO FERNÁNDEZ, op. cit., p. 432.: "Por todo ello, comparadas ambas portadas, es indudable que existe una proximidad, pero no una copia literal o una mecánica repetición, sino más bien una lograda síntesis, que constituye un desarrollo del modelo ensayado por el maestro Juan de Badajoz algún tiempo atrás en la catedral leonesa."
} 
arte de Juan de Badajoz, el Viejo ${ }^{55}$. En este sentido son destacables las similitudes estructurales entre las portadas del pórtico de Oviedo y la portada de la Cámara Santa con la portada de la librería de León y la Puerta del Cardo: el empleo de arcos carpaneles en ocasiones trasdosados con conopios, el flanqueo de los vanos con dos pilares que decrecen a medida que ganan altura, la presencia de basas de sección circular coronadas por elementos prismáticos, la talla de finos baquetones con pequeñas basas escalonadas que recorren los fustes, los remates con pináculos, la decoración con motivos vegetales, con animales fantásticos y hombrecillos desnudos...

Se suelen comparar las portadas de la Cámara Santa y del Cardo, a nuestro juicio la portada ovetense está más próxima estructuralmente a la de acceso a la librería de León. En ambas encontramos un vano de acceso abierto mediante un arco rematado en conopio cuya macolla se encuentra flanqueda por los escudos del correspondiente obispo. El enmarque del vano se compone de los dos característicos pilares de flanqueo unidos en la parte superior por una cornisa decorada con los motivos vegetales. El arco de la librería está más en la línea de los arcos del pórtico ovetense, mientras que el arco de la portada de la Cámara Santa es carpanel como el de la Portada del Cardo. Las repisas con chambrana para recibir esculturas de los pilares de la portada ovetense son comparables a las que ocupan el mismo lugar en la Portada del Cardo cuyo remate calado constituye, a nuestro entender, la culminación de la labor del entrecruzamiento de arcos con la que su autor trabaja en Oviedo.

En su día A. Meyer comparó la portada de la Cámara Santa con las de los seguidores de Simón de Colonia, y así lo recogía Francisco de Caso en su estudio ${ }^{56}$. Los rasgos generales de las portadas de Badajoz, el Viejo, son comunes a los que se pueden apreciar en portadas de Simón de Colonia como la de la Cartuja de Miraflores o en sepulcros vinculados a este autor y su cír-

\section{-}

${ }^{55}$ F. DE CASO FERNÁNDEZ, op. cit., p. 441, recogiendo una idea de W. MERINO RUBIO, op. cit., p. 179.

${ }^{56}$ F. DE CASO FERNÁNDEZ, op. cit., p. 434. El comentario de Meyer está en su obra El estilo gótico en España, 1960 , p. 66. culo, estudiados por $\mathrm{M}^{\mathrm{a}}$ Jesús Gómez Bárcena ${ }^{57}$. Estos ejemplos presentan una estructura muy similar; flanqueado por dos contrafuertes, el arco central presenta un remate conopial, se adorna con decoración vegetal y se corona con una macolla o florón a cuyos lados suele aparecer la heráldica ${ }^{58}$. Sin embargo, en lo que respecta a la decoración, a diferencia de lo que sucede en Oviedo donde el paso del tiempo evidencia el avance de la estética, en la portada del Cardo, construida entre 1514 y 1517, no se aprecia una diferencia con la decoración de la librería de un modo tan notable como en Oviedo.

Una obra como la que se llevó a cabo en la catedral no debió dejar indiferente a nadie, mucho menos a los que estarían de modo más directo en contacto con ella. Así el canónigo Pedro Solís, natural de Avilés, quiso construir en la iglesia de San Nicolás de Bari de su ciudad natal una capilla funeraria para sus padres $\mathrm{y}$ para él mismo ${ }^{59}$. La inscripción que se situó sobre la puerta, actualmente perdida, mencionaba a Pedro Solís como arcediano de Babia. Sabiendo que la licencia para trasladar los restos de sus padres a la capilla fue dada en 1498 y teniendo en cuenta que el promotor dejó de ostentar el mencionado arcedianato en 1501 se puede fechar su construcción entre esos años.

La capilla, situada a los pies y adosada al costado norte de la iglesia, es un volumen de planta rectangular con machones angulares como es propio de la arquitectura de estos momentos. La puerta de acceso desde el exterior

-

${ }^{57}$ M. J. GÓMEZ BÁRCENA, Escultura gótica funeraria en Burgos, Burgos, 1988, pp. 55, 57, 62, 75, 78, 89, 135, $142,144,164$ y 220.

${ }^{58}$ Recientemente Isidro Bango ha defendido la idea de la labor exclusivamente arquitectónica de Simón de Colonia y la posibilidad de que diese las directrices para el desarrollo de un programa decorativo que realizarían miembros de un taller, pero nunca él mismo. (Ver I. BANGO TORVISO, "Simón de Colonia y la ciudad de Burgos. Sobre la definición estilística de las segundas generaciones de familias de artistas extranjeros en los siglos XV y XVI", Actas del Congreso Internacional sobre Gil de Siloe y la escultura de su época, Burgos, 2001, pp. 51-69, especialmente 52-54.) Lo mismo podría pensarse de Juan de Badajoz en Oviedo y León; los programas decorativos son muy similares, pero elaborados por personas diferentes.

59 Actualmente la iglesia pertenece a los padres franciscanos. Sobre esta capilla F. DE CASO FERNÁNDEZ Y P. PANiagua FÉliX, El arte gótico en Asturias, Gijón, 1999, pp. 70 - 74 y V. DE LA MADRID, M. P. GARCÍA CueTOS, S. Rodríguez Vega, E. TORAL Y J. C. DE LA MADRID, El patrimonio artístico de Avilés, Avilés, 1989, pp. 157-160. 
consiste en un arco apuntado de tres roscas. Sobre la clave dos ángeles, hoy perdidos, sostenían un escudo, también perdido y a los lados se encontraba la inscripción fundacional. Una línea de imposta quebrada en el lugar donde estaban los ángeles con el escudo y las inscripciones es el último elemento ornamental por mencionar en el austero exterior. El interior está cubierto por una bóveda de terceletes, estrellada y de cinco claves, que se apoya en ménsulas decoradas con motivos toscos. La calidad de esas esculturas no tiene nada que ver con los relieves que ornamentan el arco de acceso desde la nave y la hornacina que se localiza en el testero. Aquí es donde se encuentran los mismos motivos que hemos comentado al hablar de Juan de Badajoz. Sin pasar por alto el hecho de que el acceso desde la iglesia se realiza a través de un arco enviajado de factura algo más torpe que el del tramo norte del pórtico de la catedral, encontramos los motivos de las hojas de cardo, los hombrecillos desnudos, animales reales como un mono y fantásticos como un dragón y un ave que picotea un racimo de uvas. Estos temas son muy frecuentes en la iconografía del momento y los hemos encontrado entre los motivos de la imposta de la librería de León y la puerta del Cardo, sobre todo el del ave con el racimo de uvas que en León también aparece luchando con un hombre al igual que en el tramo sur del pórtico de la catedral. Nos parece muy significativa la coincidencia de motivos, las similitudes entre algunos de ellos como por ejemplo los dragones ${ }^{60}$, y las semejanzas en la factura entre las tallas avilesinas y las que se localizan en el tramo norte del pórtico ovetense y la portada de la Cámara Santa.

A pesar de que está documentado como maestro de esta capilla Fernán Rodríguez de Borceros, en la documentación capitular ovetense se recoge un viaje a Avilés de varios días realizado por Juan de Badajoz en 1506, resaltándose el hecho de que se le descontaría el sueldo de esos días, de lo que se deduce que viajaba por un asunto ajeno a su compromiso con la catedral. La coincidencia del año del viaje con la del nombramiento de Pedro Solís deán de la catedral puede arrojar algo de luz.

\footnotetext{
${ }^{60}$ En el arco enviajado de la capilla funeraria se conserva la cola de lo que fue uno de estos dragones, la cola es muy similar a la de los dragones que aparecen en la imposta del muro meridional de la librería de León, si bien la calidad de este taller es superior a la del asturiano.
}

Pudo darse el caso de que la capilla la construyese Rodríguez de Borceros entre 1498 ó 1499 y 1501 y que en el momento de recibir su nuevo cargo, el promotor decidiese embellecer la capilla con una decoración más adecuada a su nueva condición. La diferencia de calidad con respecto a las tallas de las ménsulas habla de dos talleres muy distintos a lo que hay que unir el hecho de que la piedra de la orla de la hornacina y la decoración del arco presenta un tono más claro que la del resto, similar a la de las canteras de Laspra y Piedramuelle que abastecían a la catedral $^{61}$. El viaje de varios días que el maestro de la catedral hizo a Avilés pudo ser para visitar el emplazamiento en el que se debía ubicar la decoración que quizá tallaron los miembros de su taller.

Una vez comentadas las cuestiones acerca del pórtico susceptibles de ser comparadas con otras obras del panorama arquitectónico castellano solo queda por establecer de dónde puede proceder su tipología. Ya se ha mencionado la particularidad de la estructura del pórtico ovetense, para el que no se encuentran paralelos en la arquitectura tardogótica hispana ${ }^{62}$. Consideramos que para establecer esa procedencia es necesario despojarlo de todo elemento decorativo superfluo. Lo primero en ser diseñado tuvo que ser la estructura, consistente en un volumen paralelepipédico que se adelanta varios metros con respecto al paño de fachada, se perfora con tres arcos en la parte frontal que coinciden a su vez con las tres puertas de acceso a cada una de las naves y con dos arcos en los laterales para hacerlo practicable a modo de calle. La solución elegida para la cubierta o la decoración son elementos menos importantes puesto que quedan subordinados a la estructura general. Pues bien, ¿de dónde puede proceder entonces esa estructura? En estos momentos en los que esta investigación se encuentra aún en una fase inicial hemos localizado varios ejemplos paralelos en Francia, cuatro de ellos borgoñones, y en Alemania.

En Semur - en - Auxois (Borgoña) la iglesia de Notre - Dame recibió un pórtico de tres cuerpos frente a la fachada occidental del siglo XIV. Cada uno de sus tramos se corresponde, como en Oviedo, con una de las puertas

\footnotetext{
-

${ }^{61}$ Acerca de estas canteras ver C. LABRA GONZÁLEZ, op. cit.

${ }^{62}$ F. DE CASO FERNÁNDEZ, op. cit., p. 441.
} 
de ingreso a las naves. Al exterior se remata con una tracería calada como la que posiblemente se pensó para rematar la ovetense ${ }^{63}$. En este caso no hay aperturas en los muros laterales.

Roland Sanfaçon sitúa este pórtico dentro de la más pura tradición borgoñona y lo equipara con el de Notre-Dame-de-Auxonne ${ }^{64}$, también en el departamento de la Cote d'Or.

La comparación con el pórtico de Auxonne nos resulta más interesante aún puesto que se trata del cuerpo base de una fachada torreada en la que la torre norte quedó interrumpida y únicamente se terminó la meridional, coincidencia a la que hay que añadir la perforación del tramo sur del pórtico, que al igual que sucede en Oviedo es el basamento de una torre, por su costado meridional. Sin embargo, y a pesar de todas estas coincidencias, el pórtico de Auxonne tiene documentada su construcción a partir de 1516 bajo la dirección del maestro Loys, arquitecto de San Miguel de Dijon, y del maestro Antoine le Rupt. A estos ejemplos es necesario añadir, en la misma región de Borgoña los pórticos de San Filiberto de Dijon, del siglo XV, y de Saint Père-sous-Vézelay.

En París existen dos iglesias porticadas. Una es la Sainte Chapelle; cuya cronología, como es sabido, es anterior al caso que nos ocupa, la otra es Saint - Germain - 1'Auxerrois. La iglesia de Saint - Germain posee un pórtico occidental cuya cronología se ha establecido alrededor de 1490 y se ha vinculado siempre al ya mencionado "estilo borgoñón" una estructura de planta rectangular situada a los pies, con acceso desde sus tres fachadas, articulada en dos niveles de altura y rematada por un antepecho calado. Se sabe que en el siglo XIV se había construido un pórtico que fue rehecho hacia 1435 - 1439 y derribado en 1488 para volverlo a levantar en la década de los 90 del siglo $\mathrm{XV}$, que es el que se conserva hoy en día.

Actualmente desaparecida, la iglesia de Saint- Jacques-de-la-Boucherie, también en París, contaba con un pórtico en su fachada sur.

\footnotetext{
${ }^{63}$ La crestería que remata el tramo central no corresponde a la época de construcción del pórtico.

${ }^{64}$ R. SANFAÇON, L'architecture flamboyante en France, Québec, 1971.

65 Para cuestiones referentes a las iglesias de SaintGermain-1'Auxerrois y Saint- Jacques - de- la- Boucherie ver A. Bos, Les èglises flamboyantes de Paris. XVe.-XVIe. siècles, Paris, 2003, pp. 167-184 y 200-211.
}

La calle a la que se abría se llamaba Calle del Crucifijo pero también se la conocía como Calle del Pórtico. Hasta el acondicionamiento en los años 80 del siglo XV de la plaza a la que se abre la fachada occidental, constituyó, como en el caso anterior, el principal acceso de los parroquianos al interior del templo. No se conserva ninguna imagen del pórtico, pero es sabido que el primero de los construidos se fechaba en el siglo XIV, fue destruido en 1454 durante la ampliación de las naves pero inmediatamente sustituido por otro, levantado entre 1488 y 1491 y que desapareció en el siglo XVIII. En nuestra opinión, la importancia del pórtico dentro de la topografía de estas iglesias queda demostrada por las sucesivas reconstrucciones emprendidas $\mathrm{y}$ es interesante destacar que ambos aparecen vinculados al acceso de fieles, los clérigos entraban por otra puerta.

La catedral de Santa Cecilia de Albi, en el sur del país, se abre por su costado meridional a través de un pórtico poblado de una frondosa decoración.

En la región de Normandía hemos localizado algún ejemplo más. La iglesia de Notre Dame - de - Louviers posee un pórtico que, despojado de su exhuberante decoración flamígera, se reduce a una estructura consistente en dos pilares adelantados con respecto a la fachada que, junto con los adosados a la misma, sustentan una cubierta que cierra el pórtico abierto por sus tres fachadas a través de un arco en cada una de ellas. En la desaparecida iglesia de Saint - Vincent - de - Rouen se construyó, en la fachada occidental, un pórtico idéntico al inmediatamente mencionado en lo que respecta a estructura pero sin la decoración del anterior.

Se sabe que el que se adosa al costado meridional de Notre - Dame - en - Vaux - de Chalons - en -Champagne fue construido hacia 1525.

Junto a estos, que repiten el mismo esquema del ovetense, fueron levantados otros, como el de Notre - Dame - d'Alençon o el de Saint Maclou de Rouen cuyas plantas son poligonales. La traza poligonal es la que más se repite en los pórticos tardogóticos localizados en Alemania y territorios cercanos y podrían citarse ejemplos como las iglesias de los Santos Ulrich y Afra en Augsburgo, San Martin de Landshut o San Pedro de Regensburg. 
De planta rectangular son los pórticos de San Vito de Praga y de la Frauenkirche de Nuremberg o el de la Catedral de Ulm.

No es la cronología lo que nos interesa en estos ejemplos ni en los que mencionaré más adelante, puesto que no insinuamos que estas fachadas hayan influido de modo directo en la de Oviedo, ni mucho menos. Lo que queremos destacar es la idea de que el pórtico de la catedral de Oviedo procede de un modelo empleado en Centroeuropa en los años finales de la Edad Media.

Todos los ejemplos mencionados responden a modelos vigentes desde hacía siglos, así para Francia en el periodo gótico, además de la ya mencionada Sainte Chapelle se podrían citar, entre otros, el pórtico de San Pedro de Dijon o el levantado en uno de los brazos del transepto de la Catedral de Bayona. Hacia 1324 se fechan los dos pórticos laterales de Saint Samson de Dol de Bretagne, destacando el llamado de Saint-Magloire.

Para Alemania está más que demostrada la continuidad de uso de una estructura que procede de los "westwerk" carolingios, que se continúa utilizando en el románico y que en el renacimiento se presenta incluso en ejemplos como el de la Stadtweinhaus de Münster, muy similar al de la ya mencionada Frauenkirche de Nuremberg. Los pórticos, situados en las bases de torres únicas ubicadas en el centro de la fachada occidental de las iglesias se siguen levantando en época barroca.

De todo lo dicho aquí se debe aclarar que la enumeración de ejemplos alemanes se justifica a la hora de demostrar la difusión de estas estructuras por el territorio centroeuropeo, pero los que más vinculaciones presentan con el ovetense son los franceses, concretamente el de Saint-Germain-1'-Auxerrois y los normandos, pudiendo contemplarse la posibilidad de que el modelo llegase a Asturias a través del Atlánti$\mathrm{co}^{66}$. En este sentido, la filiación francesa del

-

${ }^{66}$ M. P. García Cuetos, Arquitectura en Asturias. 1500 - 1580. La dinastía de los Cerecedo, Tesis doctoral leída en la Universidad de Oviedo en 1992, ejemplar mecanografiado, p. 27. Se ha localizado en Oviedo la presencia de escultores de origen francés, entre ellos nos parece interesante mencionar a dos por las coincidencias de su origen con los de estos pórticos: Antonio de Borgoña; Miguel Minot, natural de Borgoña y Roberto de Ruan; pórtico enlaza con lo defendido por Pilar García Cuetos para la torre ${ }^{67}$. Sin perder de vista la posibilidad de que en Alemania también existen torres de este estilo con cuerpo inferior a modo de pórtico y aguja calada, en Francia hay varios ejemplos de torres únicas con cuerpo escalonado, contrafuertes angulares y flechas en el remate que recuerdan mucho a la de Oviedo ${ }^{68}$.

El último ejemplo que me gustaría comentar procede de una miniatura fechada hacia 1470 que forma parte del Libro de las Antigüedades de los Judios según la sentencia de José, ilustrado por Jean Fouquet. En una de las imágenes se representa la construcción del Templo de Jerusalén por orden de Salomón en la que se ve un edificio en construcción en cuya fachada se abre un pórtico, no idéntico a los mencionados pero muy similar, con tres vanos de ingreso por el costado occidental, uno por el costado meridional y es de suponer que habría otro por el septentrional. Salvando las distancias de la recargada decoración con la que se ornamenta este edificio opinamos que Jean Fouquet quiso representar en esta imagen un característico edificio borgoñón.

cuestión esta que muestra los contactos artísticos existentes entre estas regiones francesas y Oviedo.

Recientemente Raquel Alonso Álvarez ha publicado un artículo en el que esto vuelve a ponerse de relieve, ver R. Alonso Álvarez, "La Capilla de los Argüelles en San Francisco de Oviedo. Un nuevo taller septentrional en la Edad Media asturiana", Homenaje a Eloy Benito Ruano, Oviedo, 2004, pp. 591-609.

${ }^{67}$ M. P. GARCía CuETos, "Culminación y transformación de ...", pp. 88 - 89, y "Juan de Badajoz, el Viejo, entre Oviedo y León...”, p. 573-574.

${ }^{68}$ Un resumen de las influencias extranjeras en la catedral de Oviedo puede verse en C. LABRA GONZÁLEZ, "Las formas europeas en la arquitectura castellana a finales de la Edad Media", Actas del XVI Congreso Nacional de Historia del Arte, (en prensa). 


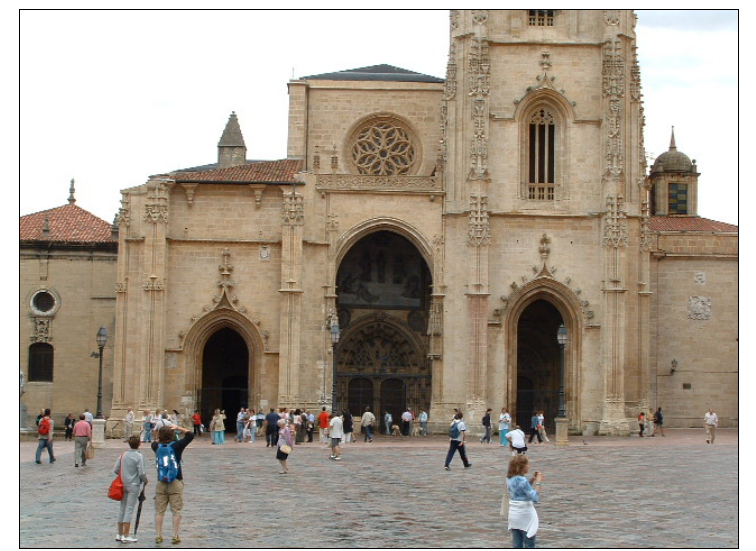

- Imagen 1. Exterior del pórtico de la catedral de Oviedo. (foto Carmen Labra).

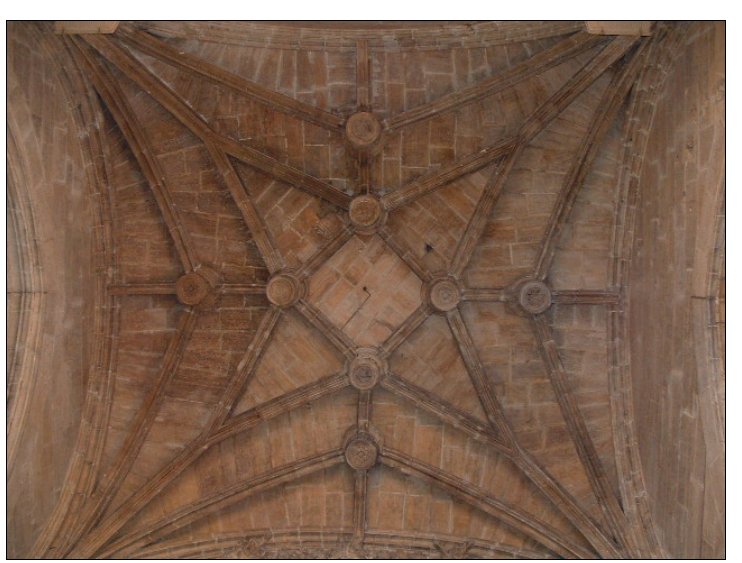

- Imagen 3. Bóveda del tramo sur del pórtico de la catedral de Oviedo. (foto Carmen Labra).

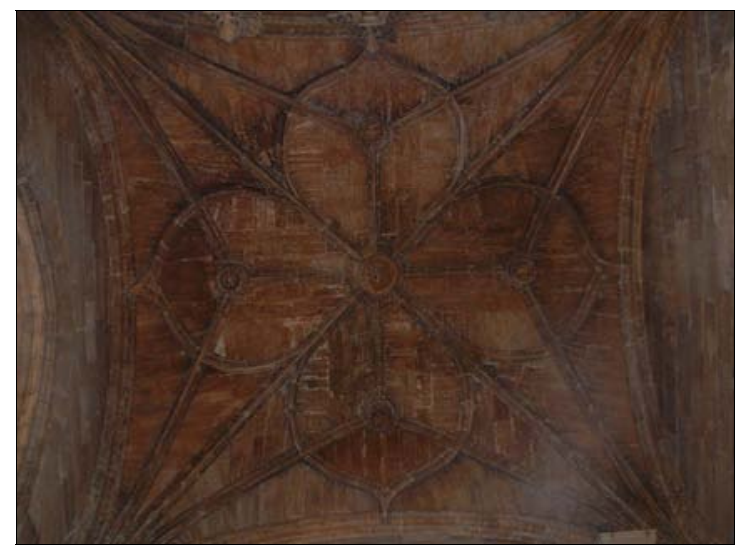

- Imagen 2. Bóveda del tramo norte del pórtico de la catedral de Oviedo. (foto Carmen Labra).

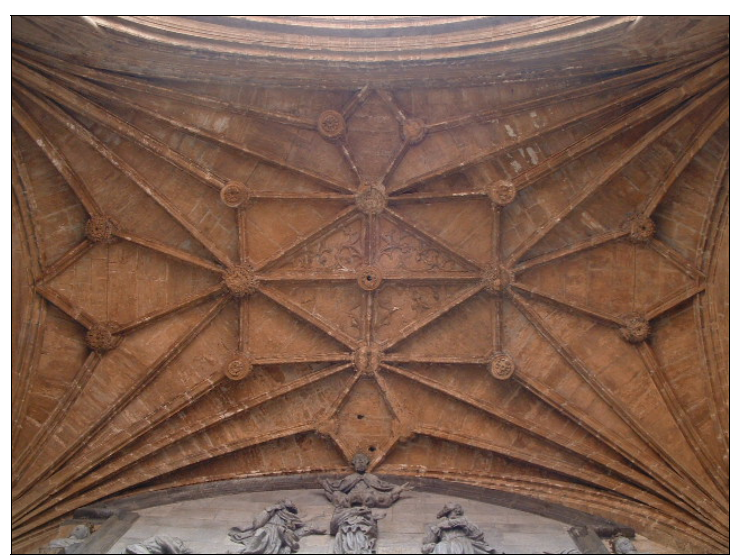

- Imagen 4. Bóveda del tramo central del pórtico de la catedral de Oviedo. (foto Carmen Labra). 


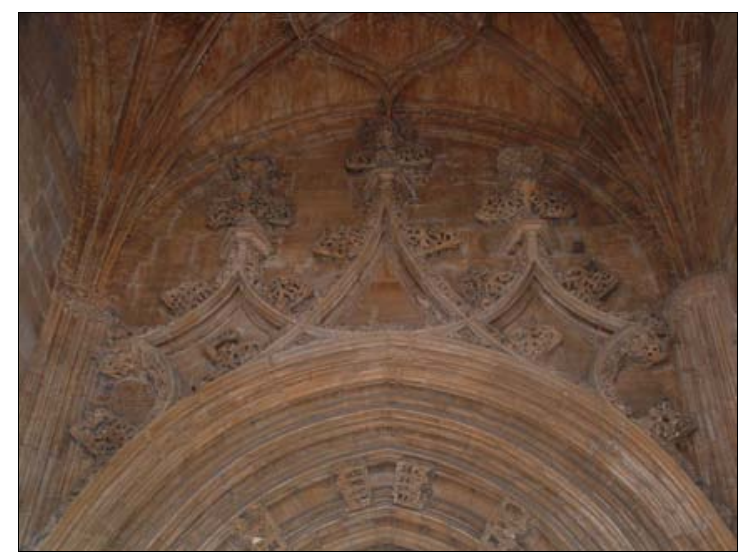

- Imagen 5. Decoración del tramo norte del pórtico de la catedral de Oviedo. (foto Carmen Labra).

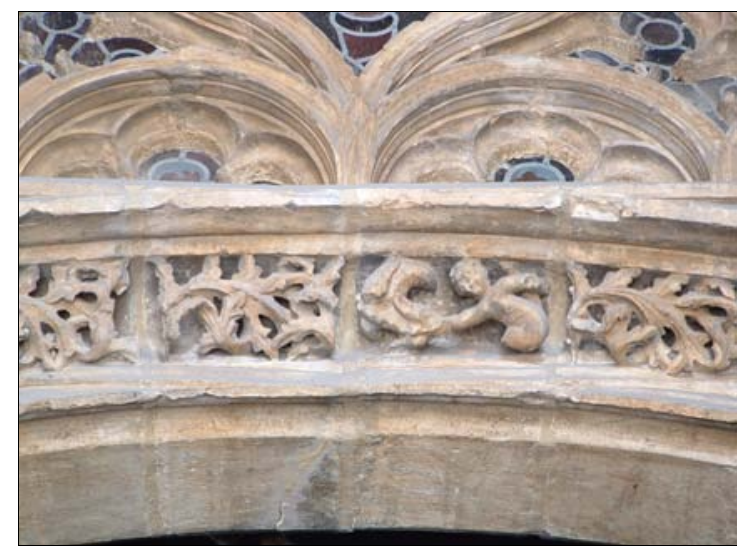

- Imagen 7. Decoración de las arquivoltas del tramo norte del pórtico de la catedral de Oviedo. (foto Carmen Labra).

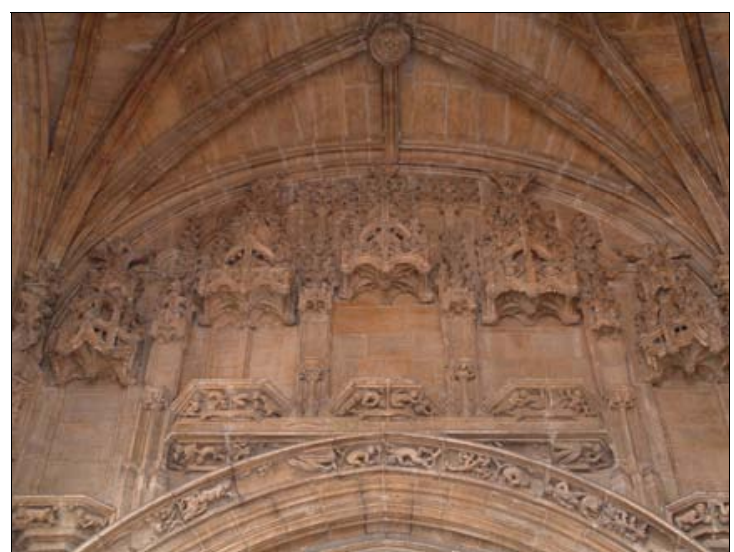

- Imagen 6. Decoración del tramo sur del pórtico de la catedral de Oviedo. (foto Carmen Labra).

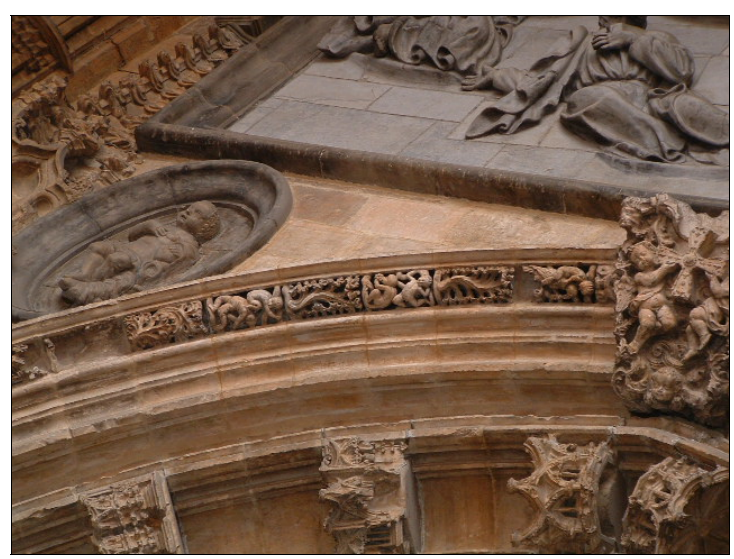

- Imagen 8. Decoración de las arquivoltas del tramo central del pórtico de la catedral de Oviedo. (foto Carmen Labra). 